\title{
Effects of Habitat, Cattle Grazing and Selective Logging on Seedling Survival and Growth in Dry Forests of Central Brazil
}

\author{
Daniel L. M. Vieira ${ }^{1}$ \\ Pós-Graduação em Ecologia, Universidade de Brasília, Caixa Postal 04457, 70919-970, Brasília, DF, Brazil
}

\begin{abstract}
Aldicir Scariot
Laboratório de Ecologia e Conservação, Embrapa - Recursos Genéticos e Biotecnologia, Caixa Postal 02372, 70770-900, Brasília, DF, Brazil

and
\end{abstract}

Karen D. Holl

Environmental Studies Department, University of California, Santa Cruz, California 95064, U.S.A.

\begin{abstract}
We studied the effect of forest gaps and cattle grazing on survival and growth of seedlings of seven native tree species, planted in dry forest fragments with different intensities of past logging in Central Brazil. Seedling survival after 12 mo ranged from 35 to 77 percent among species. Survival of most species was similar in gaps and understory in minimally disturbed forest remnants, but was lower in the gaps of more heavily logged forests. In contrast, growth was much higher in gaps than in understory in minimally disturbed forests, but for most species was similar in gaps and understory in more heavily logged forests. We did not detect an effect of cattle on seedling survival. Seedlings of the most commonly logged species show a high potential to survive and grow when planted in logged forests.
\end{abstract}

Abstract in Portugese is available at http://www.blackwell-synergy.com/loi/btp.

Key words: Astronium fraxinifolium; Cavanillesia arborea; Cerrado; Enterolobium contortisiliquum; Eugenia dysenterica; field experiments; Myracrodruon urundeuva; Schinopsis brasiliensis; Tabebuia impetiginosa; tropical deciduous forests.

TROPICAL DRY FORESTS ARE THE MOST THREATENED TROPICAL ECOSYSTEM ( Janzen 1988, Mooney et al. 1995, Khurana \& Singh 2001, Sanchez-Azofeifa et al. 2005). Dry forests of Central Brazil have been almost completely converted to agricultural lands, mainly pastures (IBGE 1995; Scariot \& Sevilha 2000, 2005). Located on highly fertile soils where the topography is flat, these forests cover only 5 percent of their original area (Andahur 2001). In addition, most of the remaining forested areas have been logged and disturbed by fire and cattle grazing for the last $40 \mathrm{yr}$ (Scariot $\&$ Sevilha 2000, Vieira 2002). Nonetheless, little research has been conducted to understand and enhance the regeneration of tropical dry forests in Brazil (Vieira \& Scariot 2006).

The most obvious impact of selective logging is the increase in canopy openness (Uhl \& Vieira 1989, Webb 1997). Increased canopy openness can promote the regeneration of light-demanding species (Holdsworth \& Uhl 1997, Bawa \& Seidler 1998, Pinard et al. 1999, Fredericksen \& Mostacedo 2000). However, seedlings in tropical dry forests are highly limited by water availability (Lieberman \& Li 1992; Marod et al. 2002; McLaren \& McDonald $2003 a, b)$. Hence, seedlings may have higher survival in shaded areas, where desiccation is less probable during the dry season

Received 19 September 2005; revision accepted 14 April 2006.

${ }^{1}$ Corresponding author; Present address: Laboratório de Ecologia e Conservação, Embrapa - Recursos Genéticos e Biotecnologia, C P 02372, 70770-900, Brasília, DF, Brazil; e-mail: dvieira@cenargen.embrapa.br
(Lieberman \& Li 1992; Ray \& Brown 1995; Gerhardt 1996; McLaren \& McDonald 2003a, b). In contrast, seedling growth may be faster in high light conditions of dry forest gaps during the rainy season (Rincon \& Huante 1993, Gerhardt 1996, McLaren \& McDonald 2003b). The balance of the trade-off in survival and growth is not clear in logged forests, where abiotic conditions are more extreme than in unlogged sites (Whitman et al. 1997, Dickinson et al. 2000).

Another frequent source of disturbance in dry forests of Central Brazil is cattle grazing inside the forest fragments (Vieira 2002). Past research suggests that large herbivores may have a strong effect on natural regeneration of forest vegetation (Relva \& Veblen 1998). Nevertheless, cattle have a patchy pattern of grazing and prefer shaded areas in these forests, where the less-dense shrub strata do not restrict movement and the canopy provides some shade during the dry season (Vieira 2002, Krzic et al. 2003). Therefore their impact on regeneration may be higher in sites with high canopy cover, although in temperate forests of Argentina cattle had higher browsing intensities in canopy gaps, where sapling density was higher than in understory (Relva \& Veblen 1998).

We conducted a factorial experiment planting seedlings of seven tree species in four forest fragments along a gradient of logging disturbance, in two habitats (gap and understory), with and without cattle present. We addressed the following questions: (1) What is the effect of treefall gaps on seedling mortality and growth? And 
how does this effect interact with season and intensity of logging? (2) Do cattle grazing and trampling decrease seedling survival? If so, does the impact of cattle vary predictably by habitat and by the degree of logging intensity?

The study was carried out in the northeast of Goiás state (Central Brazil; $\left.13^{\circ} 35^{\prime}-13^{\circ} 40^{\prime} \mathrm{S}, 46^{\circ} 44^{\prime}-46^{\circ} 46^{\prime} \mathrm{W}\right)$, in the Paranã River basin. This basin has been intensely modified by human activities, mainly by cattle ranches, which account for more than 70 percent of the regional economy (Scariot \& Sevilha 2005). The annual rainfall is $1236 \pm 50 \mathrm{~mm}$ (SE) (data from 1969 to 1994; ANA 2006) with 89 percent falling during the wet season (October to March). The mean annual temperature is $23^{\circ} \mathrm{C}$ and varies little throughout the year. The landscape is flat with limestone outcrops. The dominant soil is nitosol with a clayey texture (IBGE 1995, Scariot \& Sevilha 2005). Seasonally deciduous forest develops on these soils, with a canopy stratum between 17 and $23 \mathrm{~m}$ and a basal area of $23-28 \mathrm{~m}^{2} / \mathrm{ha}$ (Scariot \& Sevilha 2000). More than 100 tree species are found, which are characteristic of the main Brazilian biomes: savanna (Cerrado), xerophytic forest (Caatinga), and rain forest (Atlantic and Amazon Forests). Although there are few endemic species, the forest physiognomy is unique, with Combretum spp. (Combretaceae), Myracrodruon urundeuva Fr. All. (Anacardiaceae), and Tabebuia impetiginosa (Mart.) Standl. (Bignoniaceae) being the most abundant tree species (Scariot $\&$ Sevilha 2000).

We selected seven tree species that are abundant in mature forest fragments. Five are important timber species: Astronium fraxinifolium Schott, M. urundeuva, Schinopsis brasiliensis Engl. (all Anacardiaceae), T. impetiginosa, and Enterolobium contortisiliquum (Vell.) Morong (Mimosaceae) (IBGE 1995, Scariot \& Sevilha 2000). Two study species, Eugenia dysenterica DC. (Myrtaceae) and Cavanillesia arborea K. Schum. (Bombacaceae), are among the few species that have large fruits and seeds attractive to vertebrate fauna in this region (Figueiredo 2002, Vieira 2002). Eugenia dysenterica occupies the midstory while all other study species occupy the canopy strata. All species studied are classified as shade intolerant in the literature (Lorenzi 1992, Pinard et al. 1999, Lorenzi 2002, Souza et al. 2002). All species disperse seeds from the end of the dry season to the beginning of the rainy season.

From July to October seeds were collected from at least three remnant individuals of each species in pastures of the region. Seeds were germinated directly in 0.7 -liter plastic bags filled with soil from pasture surrounding the fragments. Cavanillesia arborea was germinated in 1.5-liter bags because its seeds are larger. Seeds remained in a nursery $\sim 20 \mathrm{~km}$ from outplanting sites from October 2000 to January 2001 under 25 percent shading, a light level intermediate between forest understory and gap environments. During this time seedlings received water daily until $1 \mathrm{wk}$ before outplanting, when they were exposed to full sun and received water every $2 \mathrm{~d}$ to acclimate them to field conditions. Seedlings were planted in the fragments on 1-2 February 2001 (middle of the rainy season). One week later all dead seedlings were replaced.

Four forest fragments were selected along a logging gradient: unlogged (U); lightly logged in 2000 (L1); heavily logged in 1997 (L2); and heavily logged and burned in 1997 (L3). In each fragment, plots were established in eight gaps and eight adjacent understory (nongap) sites, with all sites $>60 \mathrm{~m}$ from the fragment edge (see Sampaio 2001 showing no edge effects on the tree community). Canopy openness was much higher in gaps in L2 and L3 due to more intense logging; openness was slightly higher in understory sites in L3 because understory sites were mostly surrounded by tree gaps (Table S1).

Soil characteristics were analyzed $4 \mathrm{yr}$ after experiments were implemented, so data should be interpreted cautiously because nutrient values may have changed. We took samples at $0-10 \mathrm{~cm}$ depth for five gaps and five understory sites of eight studied in each fragment (Table S1). Overall, the burned fragment (L3) had the highest levels of soil nutrients and L2 had the highest proportion of sand. Gaps had higher concentrations of $\mathrm{Ca}$ and $\mathrm{Na}$ than understory sites.

The gaps were created by selective logging (or naturally in $\mathrm{U}$ ) $1-3.5 \mathrm{yr}$ prior to the experiment. We managed gaps before planting by cutting saplings $>2 \mathrm{~m}$ in height (residual saplings from pregap formation) to standardize gap structure within and among forest fragments. Smaller vegetation was disturbed considerably during the experiment establishment (cutting saplings, establishing fences, digging and planting seedlings). To prevent cattle access to half of the seedlings, we built sturdy $3 \times 6 \mathrm{~m}$ enclosures from wood posts and wire in each gap and understory site. One seedling of each species was planted inside and one outside of these fenced areas. Seedlings were planted on a $1 \times 1 \mathrm{~m}$ grid positioned in the center of the gap. Thus, the experimental design was: 7 species $\times 2$ canopy conditions $\times 8$ replicates $\times 2$ levels of cattle access $\times 4$ fragments $\times 1$ seedling $=896$ seedlings (128 seedlings per species). Seedlings were measured $1 \mathrm{wk}$ after planting for height of apical meristem and diameter at stem base, and then monthly for $1 \mathrm{yr}$. When possible, the cause of mortality was determined.

Survival after $1 \mathrm{yr}$ was analyzed as a function of the main effects (species, habitat, and cattle enclosure) using log-linear analysis (Statsoft 2000, Tabachnick \& Fidell 2001). Data from each fragment were analyzed independently because logging effects were not replicated. We verified the partial association of each factor and interaction, computing the likelihood ratio $\chi^{2}$ of the model that included all main factors with the model that excluded each main factor, and then repeated the process for all two-way interactions (Statsoft 2000). To select the best model we started with a model including all significant partial associations and then eliminated factors and interactions that did not improve the model at $P<0.05$ (Statsoft 2000).

To test the hypothesis that mortality in gaps is higher during the dry season, we used survival analysis (Statsoft 2000). We compared the survival curves, which describe the proportion of survivors during a period as a fraction of the number alive at the beginning of the period. The Wilcoxon test was used to compare observed to expected numbers of failure in each interval (Statsoft 2000).

Growth data were analyzed as Relative Growth Rate (RGR), calculated as: $\mathrm{RGR}(\%)=\left(\ln \mathrm{H}_{(\mathrm{t} 2)}-\ln \mathrm{H}_{(\mathrm{t} 1)} / \mathrm{t} 2-\mathrm{t} 1\right) \times 100$; where $\mathrm{H}=$ height, $\mathrm{t}=$ time in years.

For each fragment, we ran a split-plot ANOVA to test the effects of habitat (whole plot), species (split plot), and their interactions on growth in height and diameter using the PROC MIXED procedure in SAS (Littell et al. 1996). In cases of significant 


\section{Unlogged}
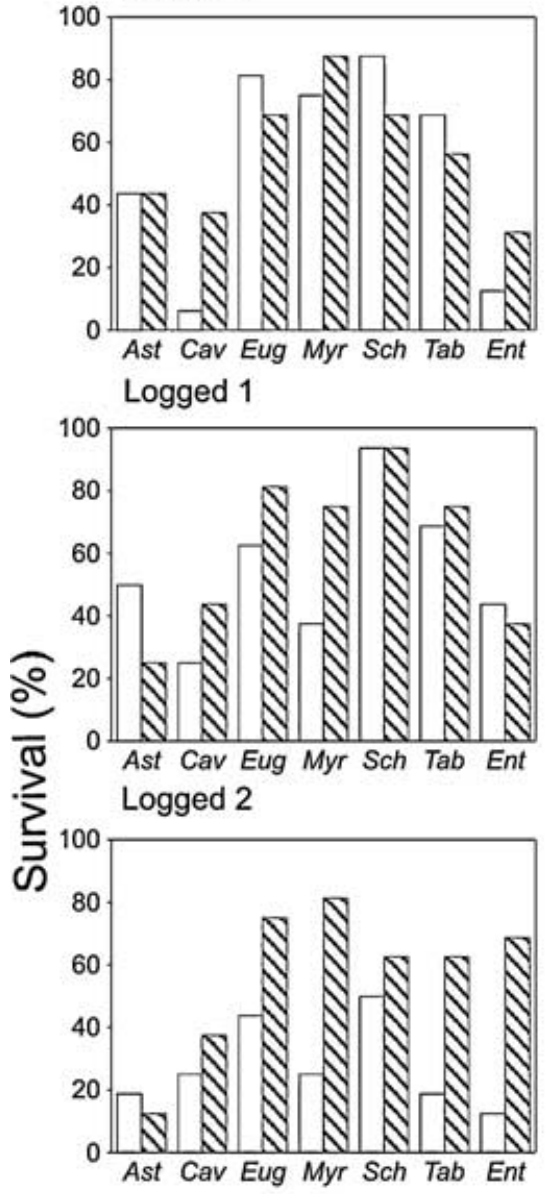

Logged 3

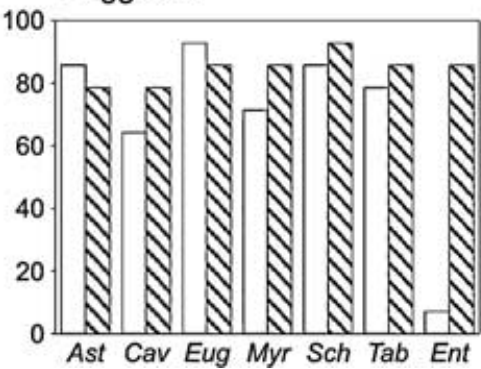

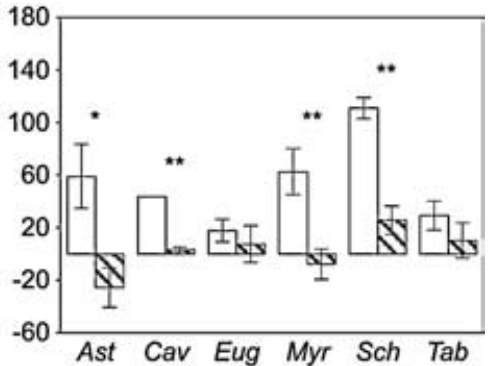
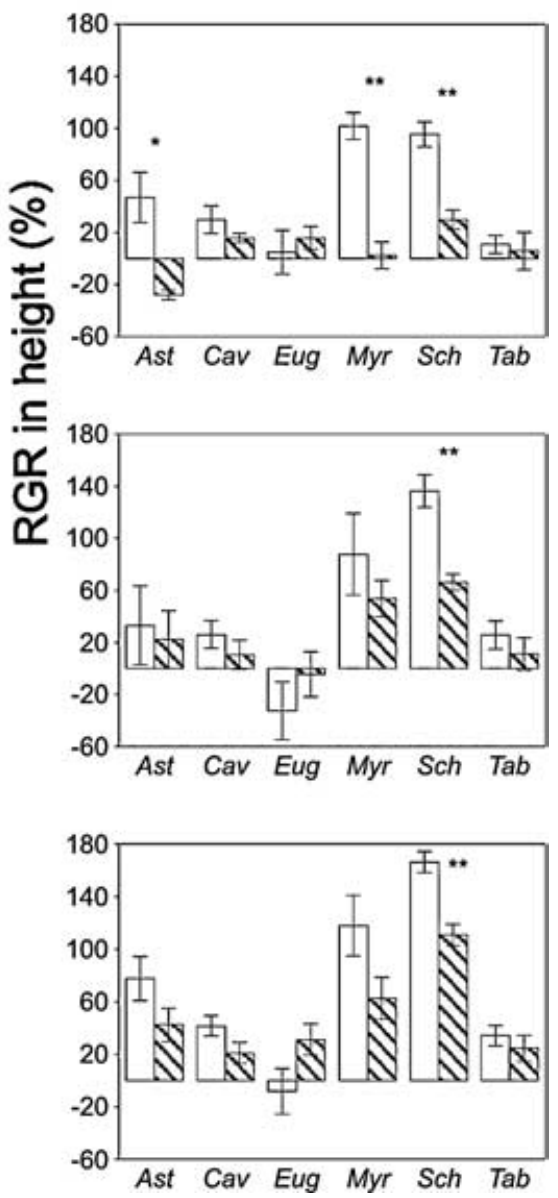

FIGURE 1. Percent survival and relative growth rate of seven species of tree seedlings after $1 \mathrm{yr}$ of planting in gap (open bars) and understory sites (shaded bars) of four forest fragments along a logging intensity gradient (Ast=Astronium, Cav = Cavanillesia, Eug = Eugenia, Myr $=$ Myracrodruon, Sch $=$ Schinopsis and Tab $=$ Tabebuia, Ent $=$ Enterolobium). Significant differences in growth between gap and understory for each species are indicated $\left({ }^{*} P<0.05\right.$; $\left.{ }^{* *} P<0.01\right)$.

interaction between habitat and species, we analyzed the habitat effect for each species by $t$-tests, using the Satterwaite approximation for degrees of freedom (Littell et al. 1996). Since diameter and height were correlated $\left(\mathrm{R}^{2}=0.54, P<0.0001\right)$ and results were the same, we only present the results for height. For growth analyses, we grouped seedlings inside and outside fences, as it was clear from our observations that no seedlings had suffered cattle herbivory. Enterolobium was excluded from growth analyses because high mortality resulted in sufficiently small seedling numbers in certain habi- tat $\times$ fragment combinations to preclude statistical comparisons of growth.

After $1 \mathrm{yr}$, overall seedling survival was 55 percent in U, 58 percent in L1, 42 percent in L2, and 77 percent in L3. Seedling survival varied among species in all fragments (Table S2), with Astronium, Cavanillesia, and Enterolobium generally showing lower overall survival than the other species in all fragments except L3 (Fig. 1). In L2, for all but one species seedlings in gaps had lower survival than in the understory. In L3, one species (Enterolobium) 


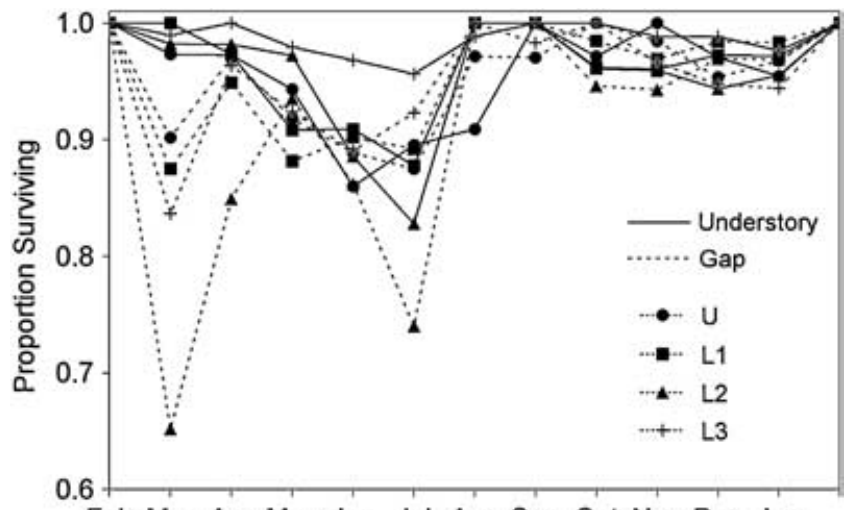

Feb Mar Apr May Jun Jul Aug Sep Oct Nov Dec Jan

FIGURE 2. Relative proportion of seedlings surviving (averaged across all seven species) over a year in gaps and understory sites of four forest fragments along a logging intensity gradient $(\mathrm{U}=$ unlogged, $\mathrm{L} 1=\operatorname{logged} 1, \mathrm{~L} 2=$ logged 2 and L3 = logged 3). Values are the proportion of seedlings surviving since the previous census.

had extremely low survival in gaps (Fig. 1). The differences in mortality in gaps compared to understory were driven by higher mortality in gaps at the end of the rainy season, after which time the survival curves in the two habitats were roughly parallel (Gehan's generalized Wilcoxon test $z=-2.07, P=0.039$ for $\mathrm{L} 1 ; z=-6.41$, $P<0.001$ for L2; and $z=-5.22, P<0.001$ for L3; Fig. 2). Survival curves were similar in gaps and the understory sites in U (Gehan's generalized Wilcoxon test $z=-0.92, P=0.357)$. Cattle did not affect 1 yr seedling survival (overall 59\% in cattle enclosures vs. 56\% outside cattle enclosures) in any of the forest fragments regardless of habitat type (Table S2).

Seedling growth varied by logging intensity, habitat, and species (Table S3). Overall there was a trend of higher growth in heavily logged fragments (L2 and L3) compared to the less-disturbed fragments (Fig. 1). In contrast to survival, growth was higher in gaps than in the understory in $\mathrm{U}$ and L1 for most species; Myracrodruon, Astronium, Schinopsis, and Cavanillesia grew at least three times faster in gaps compared to the understory in these forest fragments. In L2 and L3 there was a tendency toward higher growth in gaps, although the difference was significant only for Schinopsis. Tabebuia and Eugenia had slow growth rates in general. Negative growth potential occurred when apical meristem died and seedlings sprouted lower on the stem.

Most previous studies have shown that dry forest seedlings have higher survival in closed forest compared to open areas during the dry season (Lieberman \& Li 1992, Ray \& Brown 1995, Gerhardt 1996, McLaren \& McDonald 2003b). In contrast, in the large gaps of our more heavily logged sites, seedlings had lower survival at the end of the rainy season and beginning of the dry season, when dry spells are frequent which may result in seedling desiccation, particularly in unshaded areas (McLaren \& MacDonald 2003b). By the second half of the dry season mortality rate was similar in gaps and understory sites, which is not surprising; once the forest loses leaves during the dry season, cover differences are lower between gap and understory areas. In general, past research in moister tropical forests has shown survival to be higher in gaps than in the understory (Augspurger 1984, Osunkoya et al. 1992, Van Rheenena et al. 2004). None of our study species showed significantly higher survival in gaps, although they are all classified as shade intolerant. Rain forest understory receives 1-3 percent of full sun (Osunkoya et al. 1994) while understory in dry forest receives $c a$ 10 percent of full sun during the rainy season (Table S1; McLaren \& McDonald 2003a), so light may not be a factor limiting survival in the understory at our study site. It is difficult to explain the high mortality of Cavanillesia in general and Enterolobium in the gaps of the heavily logged sites. Both species are rare as $>1$-yr-old plants in these forests. We noted high seedling predation by termites in Cavanillesia in gaps. Successional dynamics of Brazilian dry forest species are not well understood, but it appears that Enterolobium may be highly susceptible to desiccation in open areas, although this species can grow rapidly in gaps once established (data not shown).

The fast-growing species (Astronium, Myracrodruon, and Schinopsis) grew more rapidly in gaps than in the understory in less disturbed forests, but growth was high in the understory in more heavily logged forests, reducing differences between gaps and understory in these sites. These growth trends can be explained by differences in both light and nutrients. Seedlings grow faster in heavily logged sites, as understory in highly logged sites is frequently quite open as it is surrounded by gaps (Table S1). Although the growth patterns in the two heavily logged sites are similar, L3 had proportionally higher growth for all species and canopy conditions analyzed. In fact, L3 was the only studied forest that was recently burned, and had the highest nutrient levels even $7.5 \mathrm{yr}$ after the fire event. Sites have increased nutrient availability soon after (Kennard $\&$ Gholz 2001) and even 6 yr following a fire event (Kennard 2004), which can result in enhanced seedling growth (Kennard \& Gholz 2001, Kennard 2004).

Many studies have demonstrated effects of large herbivores on natural regeneration (Relva \& Veblen 1998, Brockway \& Lewis 2003, Krzic et al. 2003). The fact that we did not detect effect of cattle on seedling survival is likely due to the low stocking rates of cattle in these forest fragments $(0.5$ cattle/ha). Estimated natural seedling density in this forest (54,000 seedlings/ha; Sampaio 2001) indicates ample available forage for cattle, and their impact is thus likely to be highly patchy. In a more recent study, with a shorter census interval in these same forest fragments, Guarino (2004) demonstrated that only five percent of seedling mortality was caused by cattle trampling. However, cattle browsing effects may be stronger during other life history stages (e.g., seed predation; Vieira 2002).

Seedling survival and growth (planted after 4 mo growing in a nursery) do not appear to represent a bottleneck to forest recovery in dry forests of Central Brazil as 57 percent of seedlings survived $1 \mathrm{yr}$ after outplanting and overall relative growth rate was 39 percent. In general seedlings show a high potential to survive and grow in the logged forests. Related research in this system suggests that germination and seedling establishment phases represent more significant barriers to forest recovery (Vieira 2002). However, open areas, such as large gaps generated by logging, can promote high seedling mortality, which could be avoided by leaving some cover and targeting planting efforts below the canopy of existing trees. The fact that seedling survival by shade-intolerant species in this study 
was not higher in gaps than in the understory - and indeed, was lower in some cases-corroborates the hypothesis that gaps are not strong promoters of niche differentiation of seedlings of tropical dry forests (Vargas-Rodriguez et al. 2005). There has been little study of which tree species are best suited for restoration of dry forests of Central Brazil; we recommend Myracrodruon and Schinopsis, as both had higher survival and growth rates across sites with a range of disturbance levels.

\section{ACKNOWLEDGMENTS}

We thank the field assistants Valdeci, Tião and Edson. P. Bueno and A. Sevilha contributed to all phases of this research. Dr. C. Cordeiro helped with statistics. The members of the Holl lab group, M. Ashton, and three anonymous reviewers improved the manuscript. DLMV was supported by CNPq grants and a fellowship from CenTREAD at UCSC. This paper is part of a project funded by GEF / BIRD / PRONABIO / PROBIO / MMA / CNPq and Embrapa-Cenargen.

\section{SUPPLEMENTARY MATERIAL}

The following supplementary material is available for this article online at: www.blackwell-synergy.com/toc/btp

Table S1, Table S2, Table S3.

\section{LITERATURE CITED}

ANA. 2006. Sistema de Informações Hidrológicas (HidroWeb), Agência Nacional de Águas. http://hidroweb.ana.gov.br.

ANDAHUR, J. P. J. V. 2001. Florestas e questôes de gestão ambiental na bacia do rio Paranã. M.Sc. Thesis. Universidade de Brasília, Brasília, Brazil.

AugSPURGER, C. K. 1984. Light requirements of Neotropical tree seedlings: A comparative study of growth and survival. J. Ecol. 72: 777-795.

BAWA, K. S., AND R. SEIDLER. 1998. Natural forest management and conservation of biodiversity in tropical forests. Conserv. Biol. 12: 46-55.

BROCKWAY, D. G., AND C. E. LEWIS. 2003. Influence of deer, cattle grazing and timber harvest on plant species diversity in a long leaf pine bluestem ecosystem. For. Ecol. Manage. 175: 49-69.

Dickinson, M. B., D. F. Whigham, and S. M. Hermann. 2000. Tree regeneration in felling and natural treefall disturbances in a semideciduous tropical forest in Mexico. For. Ecol. Manage. 134: 137-151.

Figueiredo, I. B. 2002. Padrōes de polinização e dispersão de sementes de espécies arbóreas de floresta estacional decidual, Brasil Central. Bachelor Monograph, UNESP, Instituto de Biociências, Rio Claro, Brazil.

FrederickSEN, T. S., AND B. MostACEDO. 2000. Regeneration of timber species following selection logging in a Bolivian tropical dry forest. For. Ecol. Manage. 131: 47-55.

GERHARDT, K. 1996. Effects of root competition and canopy openness on survival and growth of tree seedlings in a tropical seasonal dry forest. For. Ecol. Manage. 82: 33-48.

GUARINO, E. S. G. 2004. Germinação de sementes e estabelecimento de plântulas de árvores em florestas estacionais deciduais e pastagens abandonadas. M. Sc. Thesis, Universidade de Brasília, Brasília, Brazil.

HoldsworTh, A. R., AND C. UHL. 1997. Fire in Amazonian selectively logged rain forest and the potential for fire reduction. Ecol. Appl. 7: 713725.

IBGE. 1995. Zoneamento geoambiental e agroecológico do estado de Goiás:
Região nordeste. IBGE/Divisão de Geociências do Centro-Oeste, Rio de Janeiro, Brazil.

JANZEN, D. H., 1988. Tropical dry forest: The most endangered major tropical ecosystem. In E. O. Wilson (Ed.). Biodiversity, pp. 130-137. National Academy Press, Washington, DC.

KenNARD, D. 2004. Commercial tree regeneration 6 years after high-intensity burns in a seasonally dry forest in Bolivia. Can. J. For. Res. 34: 21992207.

KenNaRD, D. K., AND H. L. GoHlz. 2001. Effects of high- and low-intensity fires on soil properties and plant growth in a Bolivian dry forest. Plant Soil 234: 119-129.

KhURANA, E., AND J. S. Singh. 2001. Ecology of seed and seedling growth for conservation and restoration of tropical dry forest: A review. Environ. Conserv. 28: 39-52.

Krzic, M., R. F. Newman, and K. Broersma. 2003. Plant species diversity, soil quality in harvested and grazed in boreal aspen stands of northeastern British Columbia. For. Ecol. Manage. 182: 315-325.

Lieberman, D., AND M. LI. 1992. Seedling recruitment patterns in a tropical dry forest in Ghana. J. Veg. Sci. 3: 375-382.

Littell, R., G. A. Milliken, W. W. Stroup, and R. D. Wolfinger. 1996. SAS system for mixed models. SAS Institute, Cary, North Carolina.

LORENZI, H. 1992. Árvores brasileiras: Manual de identificação e cultivo de plantas arbóreas nativas do Brasil. Editora Plantarum, Nova Odessa, Brazil.

LORENZI, H. 2002. Árvores brasileiras: Manual de identificação e cultivo de plantas arbóreas nativas do Brasil vol. 2. Editora Plantarum, Nova Odessa, Brazil.

Marod, D., U. Kutintara, H. Tanaka, and T. Nakashizuka. 2002. The effects of drought and fire on seed and seedling dynamics in a tropical seasonal forest in Thailand. Plant Ecol. 161: 41-57.

Mclaren, K. P., And M. A. McDonald. 2003a. Seedling dynamics after different intensities of human disturbance in a tropical dry limestone forest in Jamaica. J. Trop. Ecol. 19: 567-578.

MCLaren, K. P., AND M. A. MCDonald. 2003b. The effects of moisture and shade on seed germination and seedling survival in a tropical dry forest in Jamaica. For. Ecol. Manage. 183: 61-75.

Mooney, H. A., S. H. Bullock, AND E. Medina. 1995. Introduction. In S. H. Bullock, H. A. Mooney, and E. Medina. (Eds.). Seasonally dry tropical forests, pp. 1-8. Cambridge University Press, New York, New York.

Osunkoya, O. O., J. E. Ash, M. S. Hopkins, AND A. W. Graham. 1992. Factors affecting survival of tree seedlings in North Queensland rainforests. Oecologia 91: 569-578.

Osunkoya, O. O., J. E. Ash, M. S. Hopkins, and A. W. Graham. 1994. Influence of seed size and seedling ecological attributes on shade-tolerance of rain-forest tree species in Northern Queensland. J. Ecol. 82: 149163.

Pinard, M. A., F. E. Putz, D. Rumíz, R. Guzmán, And A. Jardim. 1999. Ecological characterization of tree species for guiding forest management decisions in seasonally dry forests in Lomerío, Bolivia. For. Ecol. Manage. 131: 201-213.

RAY, G. J., AND B. J. BROWN. 1995. Restoring Caribbean dry forests: Evaluation of tree propagation techniques. Rest. Ecol. 3: 86-94.

ReLVA, M. A., AND T. T. Veblen. 1998. Impacts of introduced large herbivores on Austrocedrus chilensis forests in northern Patagonia, Argentina. For. Ecol. Manage. 108: 27-40.

RINCON, E., AND P. HUANTE. 1993. Growth responses of tropical deciduous tree seedlings to contrasting light conditions. Trees 7: 202-207.

Sampaio, A. B. 2001. Efeito de borda nas espécies arbóreas de uma floresta estacional decidual no Vale do Paranã. M. Sc. Thesis, Universidade de Brasília, Brasília, Brazil.

Sanchez-Azofeifa, G. A., M. Kalacska, M. Quesada, J. C. Calvo-Alvarado, J. M. NASSAR, AND J. P. RodRíGUEZ. 2005. Need for integrated research for a sustainable future in tropical dry forests. Conserv. Biol. 19: 285286.

SCARIOT, A., AND A. C. SEvilha. 2000. Diversidade, estrutura e manejo de florestas deciduais e as estratégias para a conservação. In T. B. Cavalcanti, 
and B. M. T. Walter (Eds.). Tópicos atuais em botânica: Palestras convidadas do 51o Congresso Nacional de Botânica, pp. 183-188. Embrapa Recursos Genéticos e Biotecnologia, Brasília, Brazil.

SCARIOT, A., AND A. C. SEVILHA. 2005. Biodiversidade, estrutura e conservação de florestas estacionais deciduais no Cerrado. In A. Scariot, J. C. SousaSilva, and J. M. Felfili (Eds.). Ecologia, biodiversidade e conservação do Cerrado. MMA, Brasília, Brazil.

Souza, E. R. B., R. V. Naves, I. F. Carneiro, W. M. Leandro, and J. D. BORGES. 2002. Crescimento e sobrevivência de mudas de cagaiteira (Eugenia dysenterica DC) nas condiçōes do cerrado. Rev. Bras. Frut. 24: 491-495.

Statsoft, Inc. 2000. Statistica for windows (Volume III): Statistics II, 2nd edition, Tulsa, Oklahoma.

TABACHNICK, B. G., AND L. S. FidelL. 2001. Using multivariate statistics. Allyn $\&$ Bacon, Boston, Massachusetts.

UHL, C., AND I. C. G. VIEIRA. 1989. Ecological impacts of selective logging in the Brazilian Amazon: A case study from the Paragominas region of the state of Pará. Biotropica 21: 98-106.
Van Rheenena, H. M. P. J. B., R. G. A. Boota, M. J. A. Wergera, and M. U. ULLOA. 2004. Regeneration of timber trees in a logged tropical forest in North Bolivia. For. Ecol. Manage. 200: 39-48.

Vargas-Rodriguez, Y. L., J. A. VÁZqueZ-García, and G. B. Williamson. 2005. Environmental correlates of tree and seedling-sapling distributions in a Mexican tropical dry forest. Plant Ecol. 180: 117134.

VIEIRA, D. L. M. 2002. Efeitos da exploração madeireira na estrutura e regeneração de populações de árvores de floresta estacional decidual. M.Sc. Thesis, Universidade de Brasília, Brasília, Brazil.

VIEIRA, D. L. M., AND A. SCARIOT. 2006. Principles of natural regeneration of tropical dry forests for restoration. Rest. Ecol. 14: 11-20.

WEBB, E. L. 1997. Canopy removal and residual stand damage during controlled selective logging in lowland swamp forest of northeast Costa Rica. For. Ecol. Manage. 95: 117-129.

Whitman, A. A., N. V. L. Brokaw, and J. M. Hagan. 1997. Forest damage caused by selection logging of mahogany (Swietenia macrophylla) in northern Belize. For. Ecol. Manage. 92: 87-96. 